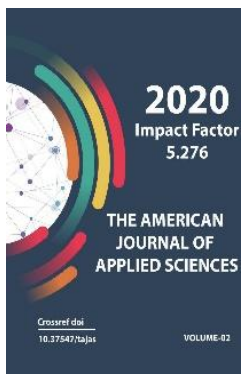

\title{
Physical Training Of Female Students Specialized In Gymnastics
}

\author{
I.I. Morgunova \\ Senior Lecturer, Department Of Gymnastics Theory And Methods, Uzbekistan State \\ University Of Physical Training And Sport, Uzbekistan
}

\begin{abstract}
Journal Website:
http://usajournalshub.c

om/index,php/tajas

Copyright: Original content from this work may be used under the terms of the creative commons attributes 4.0 licence.
\end{abstract}

\section{ABSTRACT}

The presented article examines the development of physical and technical training of students in the process of academic and training sessions of the course "Improving sports and pedagogical skills." It shows the development and improvement processes of the qualification demands through the types of all-around by years of study.

\section{KEYWORDS}

Physical and technical readiness, complex program, correlation analysis, beam and floor exercises, exercise complexes, control tests.

\section{INTRODUCTION}

Analytical review materials of special literature $(1,2,3,4)$, and data from preliminary studies of the structure and content of the educational and training process of female gymnasts of different levels of preparation ( 5 , $6,7)$ showed, that the provision of special motor preparation of female gymnasts while performing program elements on balance beam and floor exercise, is largely determined by the balanced interaction of basic physical qualities. First, it is defined by the mobility in the joints (flexibility), the manifestation of 
coordination abilities and speed-strength capabilities, the determination and courage of athletes $(1,3,6,7)$.

M.N. Umarov, co-author, $(5,6,7)$ guided by scientifically grounded results of long-term observations, reasonably conclude that in the process of mastering gymnastic exercises, the special-motor, physical and technical preparation of a gymnast is manifested in unity, in interconnection. The authors demonstrate that there is generally a close relationship ( $r=0.8790$ ) between the value of the integral indicator of the above-mentioned abilities and the success of mastering the program of the next sports category.

The objective of the research: to reveal the most significant factors influencing the level of special motor and technical readiness of students in the process of education and training sessions of the course "Sports and pedagogical skill".

\section{THE PARTICIPANTS OF THE STUDY}

To implement a wide range of theoretical and practical program requirements for a graduate of the Uzbek State University of Physical Culture and Sports (USUPCS), a pedagogical experiment was organized and conducted within 68 students specializing in artistic gymnastics (from September 2018 to June 2019 .). Before the experiment, the participants were divided into two equivalent groups (34 students in each group): experimental (EG) and control (CG). The training was carried out in the form of group lessons, since they are the most rational and allow complying with all the conditions and requirements of the pedagogical process.

\section{RESEARCH RESULTS}

When forming a complex program on physical and technical training of female students from the EG (course: 1-4, specialization: "Theory and methodology of gymnastics"), special attention was paid to the problem of consistent improvement of physical conditions, due to rational distribution of time, money and methods of training in the preparatory and final parts of academic studies, and the course "Improving sports and pedagogical skills - ISPS".

During three semesters (1-2 courses), complexes of general physical training (GPT), special physical training (SPT), and applied gymnastics (AG) exercises were used. In subsequent semesters, all work on the development of motor qualities was already built on the basis of the recommendations and normative requirements of the qualification program for physical training (PT) for the studied category.

According to the control tests, the level of physical training (PT) and technical preparation (TP) at the beginning of the experiment among the female students of the studied groups did not have significant differences ( $P>0.05$ ). The average score for the all-around types is significantly lower than the requirements of the qualifying program and fluctuates within the limits of $5.70 \pm 0.66$ and $5.58 \pm 0.74$ in physical, $6.32 \pm 0.47$ and $5.40 \pm 0.50$ points in technical readiness, respectively (assessed on a 10-point scale adopted in sports types of gymnastics). 
Table 1. The results of control tests on the physical preparation of the studied group female students upon the completion of the experiment (points)

(May 2019, 8th semester)

\begin{tabular}{|c|c|c|c|c|c|c|}
\hline \multirow[t]{2}{*}{ Indicator } & \multicolumn{4}{|c|}{$\begin{array}{l}\text { Following the conclusion of the } \\
\text { pilot }(\bar{X} \pm \delta)\end{array}$} & \multirow[t]{2}{*}{$\mathrm{t}$} & \multirow[t]{2}{*}{$P$} \\
\hline & EG & $\mathrm{V} \%$ & CG & $\mathrm{V} \%$ & & \\
\hline 1. Coordination abilities & $8.57 \pm 0.56$ & 6.5 & $6.17 \pm 0.95$ & 15.4 & $\begin{array}{l}3 . \\
3\end{array}$ & $<0.01$ \\
\hline 2. Choreographic training & $8.47 \pm 0.47$ & 5.5 & $7.07 \pm 0.97$ & 13.7 & $\begin{array}{l}3 . \\
1\end{array}$ & $<0.01$ \\
\hline 3. Power and speed training & $8.09 \pm 0.36$ & 4.4 & $7.03 \pm 1.14$ & 16.2 & $\begin{array}{l}2 . \\
0\end{array}$ & $<0.05$ \\
\hline $\begin{array}{l}\text { 4. Flexibility (mobility in } \\
\text { joints) }\end{array}$ & $9.13 \pm 0.24$ & 2.6 & $8.07 \pm 1.65$ & 20.4 & $\begin{array}{l}2 . \\
0\end{array}$ & $<0.05$ \\
\hline 5. Special stamina & $8.29 \pm 0.51$ & 6.5 & $7.20 \pm 0.84$ & 11.7 & $\begin{array}{l}2 . \\
3\end{array}$ & $<0.05$ \\
\hline 6. Average for SPT & $8.51 \pm 0.43$ & 5.05 & $7.11 \pm 1.11$ & 15.6 & $\begin{array}{l}2 . \\
4\end{array}$ & $<0.05$ \\
\hline
\end{tabular}

The materials of the conducted research on the level of PT showed that by the final semester the results of all the female students participating in the experiment increased, but not equally (table). However, the increase in SPT indicators among female students from the CG did not significantly ( $P>0.05$ ) exceed the data, recorded by us in the previous year (7.6 \pm 1.43 and $7.11 \pm 1.11$, respectively). Whereas the results from the EG increased more significantly (at $\mathrm{P}<0.01$ ) and the most significant in terms of the level of joint mobility (12.7\%), choreographic training (16.5\%), and coordination abilities (28.1\%).

The effectiveness of the proposed program for the development of motor qualities is confirmed by the progressive dynamics of the growth of indicators of the "school" of movements and physical qualities (by $16.7 \%$ ), as well as the coefficient of variation (V\%). So, the value of $\mathrm{V} \%$ fluctuations among female athletes from the EG is much more homogeneous, relative to the data of 
variation of the CG signs (5.05 and $16.5 \%$, respectively). It shows that the used means of preparation and the timely control over the process of basic gymnastics exercises "utilization" in the studied qualities are effective and can be recommended for their inclusion into the work programs of the course ISPS.

The motor skill of female athletes from the EG was formed by multiple stereotyped repetitions of movements or the studied exercise as a whole in the process of educational (academic) and training sessions of the ISPS course $(1,3,4,6)$, in particular, on a balance beam. At the same time, no significant changes were made to the structure of the exercise; it was performed, as a rule, in the same conditions. The technique of execution gradually, from semester to semester, approached the planned pattern, to the technique of exercises of the qualification program, through:

- At the first stage (1 semester): main hangs and supports, swinging in them, handstands on the floor and on stands, splits, somersaults on the floor and a low log, forward and side rolls, slow rolls. Work on the development of GPT and SPT, elementary trampoline jumping, choreographic training;

- At the second stage (2-3 semesters): combined developing exercises (CDE), AG, roundoff, flick-flack, somersault forward and backward, in the belt and foamed rubber pit, lift with an extension and two, deep jumps with a soft landing, vault with legs apart and bending legs through the vaulting horse in width and length (or jumping table), jumping on a trampoline, choreographic training;

- At the third stage (4-8 semesters): elements, combinations of stunts from the qualification program of the 2nd category, and for the most physically prepared students - of the 1st category. Work on the development of SPT, trampoline jumping, and choreographic training.

The analysis of the control and official competitions results in all-around allowed to evaluate the effectiveness of the training program developed by us and to identify the objective reasons that influenced them (Table 2 ). This increased motor (coordination, by $28.1 \%$ and choreographic, by $16.5 \%$ ) and physical preparation, by $16.7 \%$ (Table 1 ) allowed the students of the experimental group to master the more complex program "A" of the third (2nd semester). Timely start studying the elements of the second category (program "B") and show, starting from the fifth semester (8.07 \pm 0.24 points), a fairly stable, increasing result that exceeds the qualification barrier on all apparatus and the average score $(7.15 \pm 0.54$ points $)$ for the allaround control group. 


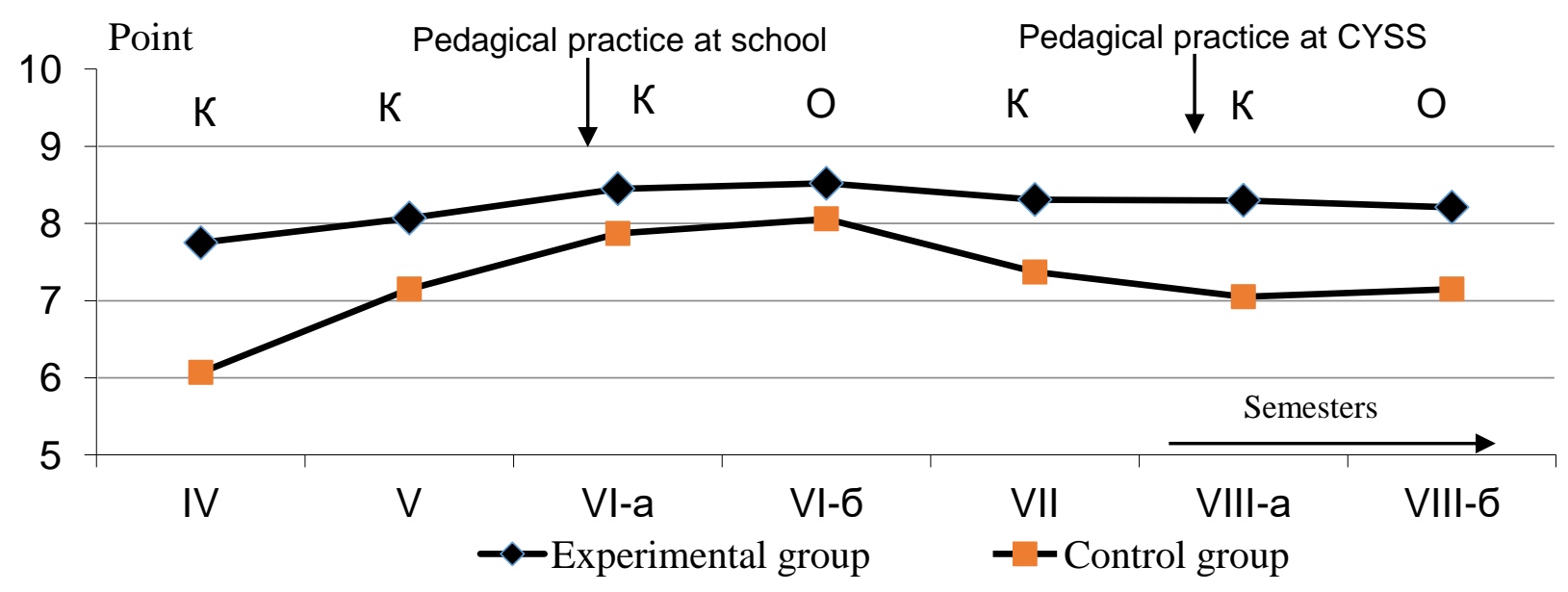

Table 2. Dynamics of the results of control (C) and official (O) competitions in the 2nd category (qualification program "b", "a") of the female students in the experimental and control groups

It is noteworthy that the majority of the female students in the control group were not able to fully master the exercises on the balance beam and uneven bars, which was recorded by us at the stage of preliminary research. The average score on these shells ranges from $7.65 \pm 0.60$ points. Whereas this indicator, according to the qualification requirements, must be at least 8.0 points. This is due, first of all, to insufficient physical preparation, which we noted above, namely, coordination and speed-strength abilities.

The results of the correlation analysis are a clear confirmation of this. The sufficiently high value of interconnection and mutual influence of the majority of the considered components are conditioned by a significant increase of specially motored readiness of female students from the EG, through the rational use of effective means of preparation and teaching methods in the process of academic studies and the course of ISPS. The increased coordination abilities directly influenced the success of teaching the elements of the program $(r=0.821)$ and the progressive development of basic physical qualities $(r=$ 0.952).

\section{CONCLUSION}

Thus, the conducted studies allowed concluding that:

- The proposed by us the variant of the rational distribution of training means in educational and training sessions (ISPS course) turned out to be the most productive in matters of consistent development of specially motor qualities and teaching program elements on the balance beam and floor exercises;

- Also, it indicates the effectiveness of the developed and experimentally substantiated training program for female students of the experimental group;

- The same gymnastic exercises present different difficulties. More physically and physically prepared female students mastered exercises for coordination and mobility in joints much easier than beginners, were more determined and courageous. At the same time, exercises requiring more complex coordination of movements (beam), great muscular tensions and special-strength endurance, given to all, without exception, female students, were much more difficult and 
needed a long process of learning and improvement;

- Successful teaching of gymnastic exercises is possible if the trainer-teacher is well aware of the requirements that artistic gymnastics imposes on students, and, consequently, the structure of the abilities necessary for the successful mastering of exercises and sports skill, the dynamics of this structure at various stages of the formation of sportsmanship; features of the relationship between individual abilities and psychophysiological mechanisms that determine this relationship; the ability to evaluate and develop abilities. At the same time, a lot depends on the pedagogical skill of the trainer-teacher, the quality of training, and education.

\section{REFERENCES}

1. Gaverdovskiy YU. K. v soavt. Sportivnaya gimnastika (muzhchiny i zhenshchiny). Primernye programmy sportivnoy podgotovki dlya DYUSSH, SDYUSSHOR i SHVSM. M.: 2005. - $511 \mathrm{~s}$.

2. Gaverdovskiy YU.K. Obuchenie sportivnym uprajneniyam. Biomexanika. Metodologiya. Didaktika. M.: Sovetskiy sport, 2008. - $912 \mathrm{~s}$.

3. Gimnastika: uchebnik dlya vuzov/Pod. red. M.L. Juravina. - M.: Akademiya, 2008. $448 \mathrm{~s}$.

4. Sosina S.S. Metodika akrobaticheskoy podgotovki yunyh gimnastok $v$ uprazhneniyah na brevne. Diss. ... kand. ped. nauk. Volgograd. 2005. -193 S.

5. Umarov M.N., Eshtaev A.K. Programmnye trebovaniya gimnastiki i tekhnologiya ih raspredeleniya po godam obucheniya //Metodicheskoe posobie. - T.: Izdatel'sko-poligraficheskiy otdel UzGIFK, 2009. -124s.

6. Umarov M.N. Nachal'naya, bazovaya podgotovki gimnastov na vidah gimnasticheskogo mnogobor'ya. // «Fan sportga». 2009. №1. -s. 32-38.

7. Umarov M.N., Hasanova G.M. Tekhnologiya ocenki special'noy fizicheskoy podgotovlennosti yunyh gimnastok //«Fan sportga». -Tashkent, 2010. -№ 3. - S. 21-24. 